\title{
Marketing Strategies of Private Islamic Schools Case Studies: Provinces in the Andaman
}

Asst.Pro.Dr.Hiran Prasarnkarn

Management science Faculty, Phuket Rajabhat University,Thailand

\begin{abstract}
This research was aimed to study 1) Current marketing strategies 2) Problems, obstacles and suggestions 3) Development of the marketing strategy for Islamic private schools in Andaman coastal provinces. This qualitative research process consists of 2 phases. The first step was to study the marketing strategy, problems, and suggestions to develop marketing strategies. The second step was the marketing strategies development for Islamic private schools in Andaman provinces. The research found as follows:

1. The Islamic private schools in the Andaman provinces used marketing strategies by presenting the schools' focus to the target groups, such as the curriculum that emphasized on moral teaching based on the Islamic principles along with academic highlights which were a unique differentiation from the general schools. The Islamic private schools used various platforms to communicate to the target groups, such as using students or teachers as personal media, traditional printed media, new media related to the Internet, guidance activities to targeted schools in the villages, corporate social responsibility activities, and school events.

2. The problems and obstacles of Islamic private schools in the Andaman provinces were the potential physical problems in reaching the students' needs to enter the schools. The time for school guidance activities were not consistent with the targeted school's time. Moreover, the schools got the potential problems for media coverage.

3. The development of marketing strategies for Islamic private schools in the Andaman provinces could be identify by using the 4C's concept of marketing that responds to the needs of consumers. There were four strategies for marketing strategies, including consumer wants and needs, consumer's cost to satisfy, convenience to buy, and communication that connects.
\end{abstract}

Keywords: marketing strategy, Islamic Private school. 


\section{BUSINESS, MANAGEMENT \& ECONOMICS}

21 - 23 JUNE 2019

VIENNA, AUSTRIA

\section{Introduction}

Nowadays, Marketing is important in every organization, even in educational business, because both government and private educational institutions tend to occupy an important market share in Educational Marketing, especially in the field of communication management. (Pakphum Dechsakulrit, 2014). At present, there are many educational institutions, causing market competition to occur. School administrators have applied marketing as a tool since 1980 (Radcliffe. 1998), which corresponds to the concept of Kotler (Kotler. 1982 : 6). He said that Marketing can be applied to both for-profit organizations and non-profit organizations. Regarding educational organization, he mentioned that "Planning analysis, plan implementation, and control by defining the programs to meet the needs of the target group can be done by explanation, persuasion and marketing services." As well as the concept of Vacaro (Vacaro. 1979) who said that there are a variety of marketing models that can be used to develop and manage education, which will lead to the existence of Educational Business, especially private educational institutions, which aims to profit as other businesses. The administrator therefore has to focus on the factors that affect the decision to continue studying at the university level. (Peerapa Pukae, 2008 : 2) Currently, State Educational institutions have absorbed marketing and profit, especially teachers and administrators established policies and visions in the manner of being entrepreneur. (Gilles, 2011)

During the past 2-3 decades, the structure of the educational market of the world has changed a lot. The number of private educational institutions is increasing, both at elementary and secondary levels. The private sectors have made great progress in providing educational services, both at the national and international levels. For the countries which are member of the Organization for Economic Cooperation and Development (OECD), the government also provides much support to students in the country. At the same time, educational institutions still have to find revenue from new sources. For example, Australia, New Zealand, the United States and the United Kingdom are leaders for public education institutions providing educational services to international students with full tuition fees. In the Asia-Pacific region, there is also a change in the structure of educational institutions with the establishment of more private educational institutions, including the establishment of branches of foreign educational institutions in the country as well. In particular, changes in competition are becoming more intense day by day, both from public and private educational institutions and foreign educational institutions that increasingly enter to manage education in Thailand. (Bootnoi and team, 2014 : 42)

The Islamic private schools have been developed and improved from educational institutions called Pondok, which is a particularly important Islamic educational institution for Muslim communities in the south. These schools started from teaching and learning in 3 southern border provinces, because most communities are Thai Muslims with Malay descent. The language used 


\section{$2^{\text {nd }}$ International Conference on BUSINESS, MANAGEMENT \& ECONOMICS}

daily is the local Malay language, including culture and living tradition are based on Islamic doctrine. Islamic private schools can respond to the lifestyle of these people as well. There are many Islamic private schools currently. They have provided more teaching and learning in the Andaman provinces, consisting of Phuket province, Phang-nga province, Krabi province, Ranong province and Trang province. There are Islamic private schools developed from traditional pondoks and many new establishments which provide teaching and learning in basic education level. These private schools are educational businesses that need to be invested. It is considered a private educational investment which is an important part of human resource development. (Pansuwan, 2013) The administrator must take into account costs and profits for the existence of the business. In addition, the marketing strategy of the educational business is different from the general strategies. Because with the recognition of the people, consumers or even the executives themselves will understand that Educational Institutions, especially organizations that focus on teaching Islam is a non-profit organization. In addition, the education is a service and product business which is intangible. Furthermore, the target group of schools which are Muslim communities in the Andaman area, a tourism economic location, has a different characteristic from other target groups. Therefore, the marketing strategy is an essential tool for Islamic private schools to convince service recipients to study at the school for the reasons mentioned above. In order to ensure the efficiency and effectiveness of Islamic private schools. Accordingly, the researcher is interested in studying to focus on developing appropriate marketing strategies for Islamic private schools in Andaman Provinces. 


\section{$2^{\text {nd }}$ International Conference on BUSINESS, MANAGEMENT \& ECONOMICS}

\section{Research objectives:}

Regarding the research of educational marketing strategies, based on a case study of Islamic private school in Andaman provinces, the researcher determined the objectives of the research as follows.

1. To study presently marketing strategies of Islamic private schools in the Andaman provinces.

2. To study the problems, obstacles and suggestions for developing the current marketing strategies of Islamic private schools in the Andaman provinces.

3. To develop marketing strategies of Islamic private schools in the Andaman provinces.

\section{Research methods}

The research of educational marketing strategies, based on case study of Islamic private school in Andaman provinces is a qualitative research. The researcher determined 2 steps of the research procedure. :

Step 1 : The study of marketing strategies, problems, obstacles and suggestions of using current marketing strategies of Islamic private schools in the Andaman provinces. This is the first step of the research to study presently marketing strategies, problems, obstacles and suggestions of using current marketing strategies of Islamic private schools in the Andaman provinces. The researcher used in-depth interview method. The key informants, who are the interviewer, are qualified as a person who acts / who is involved in recruiting new students of Islamic private schools in Andaman provinces. They are consisting of Manager or Licensee in establishing a school, Head of Academic Affairs or Head of Counseling department, with a total of 22 people. The instrument used is a questionnaire with an in-depth interview format. In order to find the quality of that tool, the researcher used the draft of the interview form to check the accuracy and clarity of the contents in accordance with the issues and objectives of the research. The researcher used 3 people of the experts in the education of Islamic private schools and a qualified person who is in charge of Islamic private schools. For analyzing the data, the researcher used the information obtained from the interview to use in the analysis and data processing process by process and method of analysis. The researcher analysed the data by considering the major themes or major pattern, then consider separating them into sub-themes and categories, which is an analysis starting from the overall analysis to synthesize sub-themes of the analysis process according to the qualitative analysis approach. In addition, during the interview process, the researcher simultaneously performed the reflecting. Especially the reflection in each range in order to have information available strength and rigor, for this research is intensively processed. As well as

4 
describing information based on phenomena to seek or acquire findings from the qualitative research process, which is a guideline for determining the marketing strategy of educational institutions in step 2 .

Step 2 : Regarding the development of marketing strategies of Islamic private schools in the Andaman provinces, there is a method of operation by raising (draft) marketing strategies of Islamic private schools in the Andaman provinces. The researcher use information from step 1 as drafting process. Analyzing the 4Cs concept of marketing was evaluated by experts, Seven qualified persons experienced in educational administration, and those who expert are in educational marketing. Then improve the marketing strategies of Islamic private schools in the Andaman provinces according to these experts' recommendations.

\section{Research results and research discussion}

\section{Research results}

Regarding the research on marketing strategies of educational institutions, case study of Islamic private school in Andaman provinces, the research results can be summarized as follow.

1. Currently marketing strategies of Islamic private school in Andaman provinces conducted by the creation of the outstanding point of Islamic private school in Andaman provinces. The research was found that the outstanding points of these schools include 1) School curriculum that emphasizes moral teaching according to Islamic principles which is creating a different strength from general schools with academic strength 2) The school has evolved from Pondok school whose founder will be a religious educator, studying from Thailand and abroad, is respected by people in the community. 3) Creating a personality based on good Islamic principles for students 4) Creating educational networks both domestically and internationally.5) Universality Scholarship 6) Corporate Social Responsibility 7) Creating a teaching environment in a small school. Teachers and school staff can take care of children thoroughly. 8) Highlights in teaching a variety of foreign languages such as Malay, English and Arabic. 9) Teaching as Pondok style like in the past 10) Tuition fee is not very expensive. 11) The school is located in a Muslim community, and 12) Continuing the art and culture of Muslims.

Regarding the method of communicating the strong points to the target group, the study found that Islamic private schools in the Andaman area allow students to apply in various aspect as follows.1) Use of students as a personal media 2) Use of printing media 3) Use of new media relating to the internet 4) Organize the counselling activities with schools in the village 5) Organize activities that show social responsibility and 6) Organize school events 


\section{BUSINESS, MANAGEMENT \& ECONOMICS}

21 - 23 JUNE 2019

VIENNA, AUSTRIA

2. Regarding problems and obstacles in the development of marketing strategies of Islamic private schools in the Andaman provinces, it was found that the problems in the development of marketing strategies of Islamic private schools in the Andaman provinces consisted of 1) Problem in the potential of accommodating the students' need to enrol. 2) Problem in time to organize schools' counselling activities, which is not consistent with the time of target schools. 3) Problems in potential of covering areas that need to communicate 4) Competitor problems. 5) Problems in the quality of school guidance and 6) Problems in the shortage of marketing personnel.

3. The development of marketing strategies of Islamic private schools in the Andaman provinces using the 4C conceptual framework of consumer's perspective Marketing focused on meeting the needs of consumers has the marketing strategies as follow. :

\subsection{Consumer Wants and Needs}

As Islamic private school in the Andaman provinces is an educational institution that meets the needs of students, parents and stakeholders in the area and nearby areas. It defines the following service curriculum strategies as follow.: 1) Development of curriculum that emphasizes teaching of moral and ethics according to Islamic principles. 2) Having a narrative about the environment of teaching Pondoks for schools that have been organizing for a long time. The school operators must present the traditional Pondok and with modern curriculum based on current world changes. 3) Internationalization of the school by developing the internationalization of teachers, for example, managing the foreign language teaching with varied and different from ordinary schools, creating an educational network with abroad educational institutions, organizing international curriculum, organizing activities to enhance English language skills for students and 4) Social responsibility expression of Islamic Schools.

3.2 Consumer's Cost to Satisfy is the total cost of students, parents and stakeholders of Islamic private schools in the Andaman provinces. It concerns about the financial cost, opportunity waste on time and emotional costs, which can set strategies of pricing the tuition fees into 2 types, including 1) Pricing by type of consumer, consisting of a high price setting for schools in areas where students' parents have good economic status and require their children to study in an international course. Another type of price setting is not very high tuition fee. Most of these schools are located in the Muslim community. 2) Setting a price strategy that encourages parents to send their children to school. There are many schools that use price strategies to convince parents to send their children to school. For example, when parents send their first child to school, the second child will get 50 percent discount, providing scholarships to orphaned students or lack of funds

3.3 Convenience to buy is the curriculum and educational service of Islamic private schools in 
Andaman provinces. Students and stakeholders are easily accessible and ready to provide services. It is a way for students, parents and stakeholders can access educational services of Islamic private schools. Determine the distribution channel strategy, which is considered as one of the most important decisions for executives, because it affects the response of the target group in various matters, such as the participation of stakeholders, utilization of educational services, and creating religious activities together with communities, etc. The educational service is a popular channel, which is a direct service channel to the target group, such as making decisions about the school's location and educational service center, etc.

3.4 Communication that Connects is the communication process through marketing tools to inform news, including providing knowledge about the behavior that needs to occur, and convince the target market to follow. It is defined as a marketing communication strategy of Islamic private schools in Andaman provinces by 2 issues as follow.

$1^{\text {st }}$ issue : The main information that the school uses to communicate (Core message), Islamic private schools in the Andaman provinces should be to communicate the primary data with target groups and stakeholders through philosophy, vision and mission as follows. : 1) Being a school that produces students with knowledge and abilities of religious and academic. In addition, the schools can produce quality Muslims that can be religious leaders in the community. 2) It is a school that enhances language skills, especially languages that are different from ordinary schools, such as Malay, Arabic, etc. These practices are for contributing to the internationalization of the curriculum in schools, and 3) It is a school that creates educational opportunities for orphaned students or students who are in need of money.

$2^{\text {nd }}$ issue : Communication methods to the target group. Regarding the research results, it is found that every private Islamic school should use various communication methods, including 1) Using Personal Media, such as word of mouth publicity, Visiting students' home, Using teachers and students to guide in their own communities, Using alumni networks, etc. 2) Using traditional media such as notice board, brochure, school billboard, poster, vinyl board 3) Using new media related to the internet (New Media) such as website, facebook, line group, which are more likely to use. 4) Organizing Community relations such as arrange students to read Khutba in Friday prayer in the mosque of the community, helping affairs in the mosque of the village, Nazaya prayer (funeral ceremony), being a lecturer in the community to teach religion.

\section{Research Discussion}

The research of "Marketing strategies of private Islamic schools", case studies: Provinces in the Andaman refer to the research results about marketing strategies of Islamic private schools in the 
Andaman province, presented by the researcher with 4Cs concept consisting of Consumer Wants and Needs, Consumer's Cost to Satisfy, Convenience to buy, and Communication that Connects as the research results mentioned above. Due to the increasing number of Islamic schools in the Andaman area with more competition, the researcher therefore used the research results to discuss, by referring to the theory of Business Competitive Advantage of Michale E Porter (1985) as following details.

1. Use Consumer Wants and Needs to create a selling point for products or services to be different from competitors (Differentiation), which is satisfied by the target group, the parent of the student. Some schools in Phuket can set a high price, because of the identity that makes a difference to Islamic private schools in the Andaman province as a selling point. In regard to establishing the strong point of Islamic private schools in the Andaman provinces, the research was found that the outstanding point of the school needed by the target group including 1) Development of curriculum that emphasizes moral and ethics teaching based on Islamic principles. 2) Having a narrative about the environment of teaching Pondoks for schools that have been organizing for a long time. The school operators must present the traditional Pondok and with modern curriculum based on current world changes 3) Internationalization of the school by developing the internationalization of teachers, for example, managing the foreign language teaching with varied and different from ordinary schools, creating an educational network with abroad educational institutions, organizing international curriculum, organizing activities to enhance English language skills for students, and 4) 4) Social responsibility expression of Islamic Schools.

The creation of the above selling point can be considered as creating a product selling point. The school provides curriculum promoting morality in accordance with Islamic principles for students. The students who attend these schools can practice religious according to Islamic principles, have strict discipline in praying 5 times a day, being an imam that can brings prayers, can read Al-Quran Bible, and can apply the principles of Islam to life. The above mention is a concrete achievement seen in the perspective of parents who send their children to study in these schools. Furthermore, there is also foreign language ability in Malay or Arabic which is a different skill from students in ordinary schools. This ability will lead to educational opportunities for students who are going to study abroad. The above outstanding point create differentiation in products or services of Islamic private schools that can still be desired by the target group. If the target group is satisfied with the school curriculum, will cause loyalty to the product or service and decide to send other children to study. It is consistent with the research of Sorawana Sangsuk, Bandit Pangniran and Booncherd Pinyoanantapong (2014), studying the strategy of differentiation for competitive advantage of one Tambon One Product, ceramic products in the lower northern part of Thailand. The research was found that the product differentiation and empirical variables that can explain relationships from descending is the 


\section{BUSINESS, MANAGEMENT \& ECONOMICS}

21 - 23 JUNE 2019

VIENNA, AUSTRIA

quality difference. Product quality is the key to create the differentiation of products that will make consumers impressed and eventually become loyal to the product. Manufacturers or distributors of products that properly differentiate in quality of goods will make the product look good, valuable, and reliable in use. Including the different physical characteristics of products, as well as being safe to use, make consumers decide to buy.

In addition, it is consistent with the research of Jumderm and Saomuang (2013), which studied marketing strategies of private vocational education institutions in Thailand. The research found that there are elements of variables in the image of the school is part of the management of marketing strategies of educational institutions and affects achievements consisting of teaching and learning facilities, the quality of the teacher, school environment, the quality of students and the process of studying. Furthermore, the research results are also consistent with the research on elements of marketing strategies that influence the success of private schools of Ungsujinda (2010) which indicates the research results that marketing strategies for private school products consist of important components as follow : Educational technology, Organization of the flexible curriculum that encourage students to be ready for life, Organize learning activities with studentfocused, and information technology for education used in education management and knowledge development.

The research results indicate that the quality of course, teaching management, and the image of the school are the primary factors that allows parents to send their children to study, which is consistent with the research of Suwanwong (2017). The research was found that factors affecting the decision to study at the undergraduate level in Rajamangala University of Technology Isan (by quota admission) in academic year 2017 consist of University image, being a famous state university for a long time, having good and knowledgeable faculty, and being accepted by the sources of work after graduating.

Therefore, creating product differentiation of Islamic private schools that are in line with the needs of parents and students affects the purchasing decisions of consumers and can lead to loyalty to products or services. The parents will send the next offspring to study at that school as their 1st child.

2. Consumer's Cost to Satisfy leads to the Cost Leadership of private school's business operators. Islamic private school administrators must have skills in cost management, manage teaching with quality courses, provide quality instructors, and manage the school to have a good physical environment. If administrator can manage costs efficiently, it is an opportunity to use a price strategy to convince the target group to study at the school. By reason of setting low prices for products or services to be able to sell products in large quantity and customers. The research 
results was found that Islamic private school in Andaman provinces have used price structures to manage their own marketing strategies. There are 2 ways to set the price, including 1) Pricing by type of consumer, for schools in areas where parents, students, have good economic status and require an international course. Another is not very high price setting. Most of these schools are schools located in the Muslim community. 2) Setting a price strategy that encourages parents to send their children to school. There are many schools that use price strategies to convince parents to send their children to school. When the parents send their first child to study, the next child will get 50 percent reduction, or providing scholarships to orphaned students, or lack of funds.

However, setting a high price is possible with schools with specific target groups, which is mainly located in Phuket. Private religious schools in other areas often use a very low pricing strategy to convince parents to send their children to attend in the school. The results of this research are consistent with the research of Ungsujinda (2010) which mentioned that the price strategy of private schools is important for the parents' decision to send their children to study at the school, for example, the administrator has a policy to reduce tuition fees to 3-4 brothers and sisters in the school, administrator has a policy to reduce tuition fees in the case of families experiencing economic problems, the school grants scholarships to students who are exempt from tuition fee, the school grants scholarships to students as funding for children, and scholarship consideration by considering the overall picture together.

In addition, it is consistent with the research of Sereerat, Jornjit and Pichai (2018) who studied about factors that determine the decision to study at the vocational level of students in the southern provinces of the Gulf of Thailand. The result was found that factors that determine the decision to study at the vocational level of students is the family factor. The economic status of the parents affects the pricing of school operators and in accordance with the research results of Jangaksorn (2010). The research was found a second variable to predict the decision in choosing to study in vocational education of Matthayom 3 students is the level of parent's support. It is also consistent with the research of Kamsamran and team (2010) that study about marketing strategies of private vocational school at the vocational level. The overall highest level is the tuition fee, which is consistent with the research of Konggapan (2010) that studied the factors affecting the selection of higher education institutions of vocational students in Phuket and Phangnga provinces. The study showed that the factors of productivity and quality of students, teaching and learning process, building and location and price are important factors in the decision to choose to study higher education institutions of vocational education. In addition, referring to the research of Madmaen (2014), studying about the marketing strategy to develop the image of private vocational colleges in Thailand, was found that the management of private vocational colleges have relationship with marketing strategy and also have a direct relationship with the image of private vocational colleges, which directly affects student's loyalty. In particular, education fees are the most important parameters of the marketing strategy. 
Therefore, the reasonable pricing of Islamic private schools must consider many factors related to pricing, such as economic status of parents, courses innovation, consistency of educational results and the needs of students and parents, quality of teaching and learning management, including the physical characteristics of the school. The pricing strategy would continue and link from product strategy.

3. Convenience to buy and Communication that Connects lead to Niche or Focus Strategy are strategies aiming at serving specific customer groups. The strategy that private educational institutions use to focus on specific groups is that each educational institution will have personnel that advertise educational institutions in order to acquire students who attend the school. If it is a higher education institution, there will be a provincial center to facilitate this matter, being a center for coordinating by region, providing advertisement about the institution, etc. These actions affect interest from those who are going to decide to study in the region, resulting in a decrease in the number of state and private educational institutions in the region. Regarding the educational institutions of the region, there is personnel acting educational institution advertising in order to acquire students who attend the school as well by using strategies to meet the target group students who are about to graduate at their schools, give away leaflets and bring students, undergraduate students who are alumni to meet the younger generation, persuade the younger generation to participate in public relations advertisements as well by wearing a student uniform of the institution where they are studying. This is because the uniform is the main factor that makes the students decide to study for the first reason.

Regarding to market specifics (Focus) of Islamic private schools in the Andaman area, most of the target groups are youth in the community or nearby communities and there may be students from other provinces. Regarded as a business that focuses on producing products or services for the Niche Market a particular market. Therefore, with specific products and services, then it will be able to set high selling price, for example, organizing international curriculum, because the parents in new generation have a higher interest, and do not want to risk to buy international course services from schools that do not teach religious courses.

The researcher considers that the heart of the marketing of private schools in the Andamana area is to make a strategy to make a difference (Differentiation). While doing business with no difference from competitors, means that entrepreneurs are facing the risk of snatched students at any time. Therefore, Islamic private school administrators should design courses by creating educational innovations in teaching and learning, creating curriculums with a unique identity of an Islamic private school in Andaman provinces, and creating a clear image in the perception of the target groups and stakeholders in order to make a difference that is more sustainable than competitors. 


\section{BUSINESS, MANAGEMENT \& ECONOMICS}

\section{Suggestion}

\section{Suggestions for applying research results}

1.1 Islamic private schools in the Andaman area should start marketing strategies from researching the needs of the target group in order to obtain in-depth and realistic information before using that information for planning. According to the research results, it was found that Islamic private school operators in the Andaman area know the methods of advertising, publicity, program development and program and service accessibility at the highest level, representing as 100 percent. As for the least known methods of private Islamic school operators in the Andaman area include advertising research, marketing research, advertising research, the use of marketing committee, the use of a marketing director, and pricing.

1.2 Every school must maintain the strength of the school about building moral values according to Islamic principles along with enhancing the academic capacity of youth. As this is the main factor that allows parents to still send their children to attend the religious schools. In addition, this group of parents still has strong ideas about letting their children to learn religion by the reason of their religious faith.

1.3 Creating highlight of language skill to contribute to the internationalization of the school is another important feature that Islamic private school administrators have to consider, because the language skill makes students in these schools different from ordinary schools, and may be a good basis for their future work.

1.4 Creating educational innovations, including the teaching and learning method, providing modern courses are important adaptation of the curriculum in Islamic private schools, especially in the Andaman area, where most provinces contain tourist attractions. Parents have better economic status, and more educated. Therefore, the curriculum adaptation is important in attracting the attention of new generation parents. For example, raising the selling point of entrepreneurship, respond to the Digital Transformation. However, it depends on the executive's vision. Creating habits and skills of being an entrepreneur (Entrepreneurship) affects students' future work. When looking at the future, the world maybe full of new professions that people in this era may not imagine. Therefore, students must have skills to solve problems, have the courage to make decisions, and have a lot of creativity for dealing with those futures. In addition, the school must teach the students about the systematic thinking through the teaching of program coding and robot connection. Most importantly, a study in the world of next generation should focus on sincerity that the school intends to develop students to have real potential. The success measure is the person who is the best public relations department of the school. They are not the authorities in public relations department of the school, but parents who send their children to 


\section{$2^{\text {nd }}$ International Conference on BUSINESS, MANAGEMENT \& ECONOMICS}

study will assess about which school should be trusted. While the school continues to strengthen good morals according to Islamic principles.

1.5 Schools should have an assessment of the performance according to the marketing strategy about which is the most effective form of marketing communication to the target group, and how it affects the decision to choose to study at the school.

\section{Suggestions for further research}

2.1 In this research, the researchers used data analysis with 4C's concept. Perspective of target groups and stakeholders of Islamic private schools in the Andaman provinces is to synthesize marketing strategies. The next research should be studied Holistic Marketing Approach, both the perspective of the target group and stakeholders in parallel with the administrator's perspective or business operators of Islamic private schools in the Andaman provinces.

2.2 It should study the success factors of the administration of Islamic religious schools in the Andaman provinces, or a marketing platform that responds to the needs of target groups and stakeholders with a unique characteristic of parents as business people in the area. It affects the demand for educational services with distinctive identities and different from Muslims in other areas.

\section{References}

Bootnoi, N and team. (2014) : University sustainability : Case study of Lampang Rajabhat University. The 3rd National Academic Conference, Phuket Rajabhat University : 2014 "Integration of Thai Research within the ASEAN Community Network"

Dechsakulrit, P. (2014). Educational Marketing.

[online]. Available :http://www.thansettakij.com/[2558, December 20].

Jumderm, A and Saomuang, S. (2013). "Marketing strategies of private vocational education institutions in Thailand" EAU Heritage Journal Science and Technology. Year 3 Issue 2 July December 2013, Page 114-124.

Jangaksorn, N. (2010). Needs and factors affecting the decision to study in vocational education of Mattayomsuksa 3 students : Analysis of discriminant factors (Thesis of Master of Education Program in Educational Research Methodology). Bangkok : Graduate School Chulalongkorn University. 


\section{$2^{\text {nd }}$ International Conference on BUSINESS, MANAGEMENT \& ECONOMICS}

$21-23$ JUNE 2019

VIENNA, AUSTRIA

Konggapan, R. (2010). Factors affecting the selection of higher education institutions of vocational students in Phuket and Phang Nga province. (Thesis of Master of Education). Nonthaburi : Rajapruk University.

Kottler, P. (1982). Marketing for nonprofit organization ( $2^{\text {nd }}$ ed.). Englewood Cliffs, NJ :Prentce-Hall.

Kotler, P. \& Fox, K. F. (1985).Strategic marketing for educational institutions. Englewood Cliffs, NJ : Prentice - Hall.

Madmaen, P. (2014). Marketing strategies for developing the image of private vocational colleges in Thailand. (Dissertation of Doctor of Business Administration). Bangkok : Siam University.

Pansuwan, S. (2013). Analyze marketing communication for private kindergartens schools. Thesis of Master of Communication Arts of Dhurakij Pundit University.

Pukae, P. (2008). Marketing mix factors affecting the decision to choose to study at the undergraduate level in private universities, case study of Sripatum University, Chonburi campus. Independent research of Master of Business Administration.

Redcliffe, R.. (1998). Effects of Marketing and program structure on curriculum

and enrollment in precollegiat summers. Unpublished doctoral dissertation, University of Denver.

Sangsuk,S. Pangniran, B. and Pinyoanantapong, B. (2014). "Differentiation strategies for competitive advantage of one Tambon One Product, ceramic products in the lower northern part of Thailand". Social Sciences Research and Academic Journal. Year 9 Issue 26 (May- August). Page 43-60.

Sereera,p. Jornjit,S. And Pichai, P. (2018). "The discriminating factors for decision making towards further vocational education of students in the southern provinces of the Gulf of Thailand" Journal of Humanities and Social Sciences Mahasarakham University.113. Year 37 Issue 3 (May - June) Page 111-123.

Suwanwong, N. (2017). Factors affecting the decision to choose to study at the bachelor's degree level In Rajamangala University of Technology Isan Nakhon Ratchasima (Quota System) Academic Year 2017. Office of Academic Promotion and Registration Rajamangala University of Technology northeast.

Ungsujinda, S. (2010). Elements of marketing strategies influencing the success of private schools. Doctor of Philosophy of Christian University. 


\section{$2^{\text {nd }}$ International Conference on BUSINESS, MANAGEMENT \& ECONOMICS}

ICBMECONF

21 - 23 JUNE 2019

VIENNA, AUSTRIA

Vacaro, J.. (1979). Marketing on the college campus : Underdeveloped or

oversold? Marketing Review,47-59 